\title{
HEAVY METAL CONTENT IN THE BARK OF CAMPHORA TREE IN XIANGTAN AND ITS ENVIRONMENTAL SIGNIFICANCE
}

\author{
ZHANG, Y. ${ }^{*}-$ XIANG, Y. B. ${ }^{2}-$ CHEN, W. Y. ${ }^{1}$ \\ ${ }^{\text {I} S c h o o l ~ o f ~ R e s o u r c e, ~ E n v i r o n m e n t ~ a n d ~ S a f e t y ~ E n g i n e e r i n g, ~ H u n a n ~ U n i v e r s i t y ~ o f ~ S c i e n c e ~ a n d ~}$ \\ Technology, Taoyuan Road, Xiangtan, Hunan Province, China \\ ${ }^{2}$ School of Architecture and Art Design, Hunan University of Science and Technology, Taoyuan \\ Road, Xiangtan, Hunan Province, China \\ *Corresponding author \\ e-mail:292278@qq.com; phone: +86-151-7326-5757
}

(Received 28 $8^{\text {th }}$ Mar 2019; accepted $22^{\text {nd }}$ May 2019)

\begin{abstract}
With rapid economic development, Xiangtan, as an old industrial base of China and a famous industrial city in Hunan Province, caused severe pollution, which had a significant impact on people's lives. To understand the heavy metal pollution in Xiangtan, we tested and analyzed the barks of Cinnamoтum camphora in different functional areas. The article examined the differences and sources of heavy metal contents in the bark of Cinnamomum camphora from different functional areas. The results showed that the contents of various heavy metals in the barks of Cinnamomum camphora varied considerably and the most common elements of heavy metal pollution were $\mathrm{Mn}, \mathrm{Pb}$, and $\mathrm{Cr}$. The activities in different functional areas had a significant influence on the enrichment of heavy metals in the bark of Cinnamomum camphora. Heavy metals in the business district mainly came from traffic emissions and various domestic wastes. High population density and household litter affected the heavy metal contents in the Residential District. Heavy metal contents were high in parts of the urban green space due to living garbage or surrounding environment.
\end{abstract}

Keywords: pollution, functional areas, spatial distribution, bark, indicator

\section{Introduction}

With the rapid development of the global economy, pollutants containing various heavy metals enter the environment in different ways. Heavy metal pollution can gradually become a serious environmental issue. The hazards of heavy metals including both existing and potential forms have an almost irreversible effect on ecosystems and human health (Sun et al., 2011; Zhang et al., 2012, 1998). Heavy metal pollution has many characteristics, including latency, cumulativeness, long lifespan, and irreversibility. If we do not take immediate and effective measures, it will have a more severe impact. Heavy metals in the environment mainly come from gas emissions, road traffic emissions and industrial emissions (Yao et al., 2012; Zhang et al., 2012). Previous studies showed that heavy metals in plant surface often decreased with increasing distance from pollution sources (Zhu et al., 2007; Chen et al., 2016).

There are various methods to detect atmospheric heavy metal pollution. Broadleaved and coniferous trees, such as mosses, lichens, vascular plants, and woody-plants, can be utilized to study air pollution (Sun et al., 2011; Huang et al., 1983, 1984; Fang et al., 2000). Because the surface layer of plant contacts more with the atmosphere and is sensitive to environmental changes, it becomes a significant carrier for monitoring air pollution. Though barks do not absorb heavy metals and other pollutants sensitively as mosses do, it is a good indicator of other contaminants, such as electrical conductivity, $\mathrm{pH}$, sulfur, nitrogen, heavy metals, and so on (El-Hasan et al., 2003). Because 
Cinnamomum camphora is a street tree and its bark is exposed to the atmosphere for a long time, it has a large contact area with the atmosphere. Barks of Cinnamomum camphora not only contained heavy metal elements absorbed from the soil but also accumulated a large amount of dust and particles from the atmosphere (Huang et al., 1983; Zhou et al., 2014). Therefore, this paper chose barks of Cinnamomum camphora as an indicator of air pollution to study.

Xiangtan is an old industrial city. In recent years, with the continuous development of industry and economy, the heavy metal contents of Xiangtan have increased sharply. This study tries to analyze the spatial distribution characteristics of heavy metal in the barks of Cinnamomum camphora in Xiangtan, reveal the sources and causes of heavy metal pollution, and explore the pollution situation. This study can not only investigate the causes and extent of heavy metal pollution in Xiangtan City but also provide a scientific basis for ecological research in urban areas. It is also helpful to environmental governance, human health, urban eco-environment, and sustainable urban development.

\section{Materials and methods}

\section{Research area}

Xiangtan City $\left(111^{\circ} 58^{\prime} \mathrm{E}-113^{\circ} 05^{\prime} \mathrm{E}, 27^{\circ} 21^{\prime} \mathrm{N}-28^{\circ} 05^{\prime} \mathrm{N}\right)$ is a prefecture-level city in the east-central of Hunan Province, with a total area of $5015 \mathrm{~km}^{2}$. It is the smallest prefecture-level city in Hunan Province, China. In 2010, the city's resident population was 2.748 million, of which 959,000 were in the urban area, with a population density of 549 people $/ \mathrm{km}^{2}$, ranking second in Hunan Province. The climate of Xiangtan belongs to a subtropical monsoon humid climate with abundant precipitation, sufficient solar and thermal resources. Although the annual rainfall reached $1200-1500 \mathrm{~mm}$, the time distribution was uneven, and the inter-annual variability was considerable (Xiao, 1996).

Xiangtan's geographical position is superior. Many expressways and railways meet and pass here, which is highly beneficial to the economic development of Xiangtan. Simultaneously, Xiangtan, together with Changsha and Zhuzhou, is the "Golden Triangle" urban agglomeration with the most developed politics, economy and culture in Hunan Province (Xiao, 1996). In recent years, Xiangtan's economy has been growing, especially in various industries. Xiangtan has grown up to be a heavy industrial city with mechanical, metallurgical, chemical and textile industries. Main industrial types include coal, metallurgy, chemical fiber, chemical industry, textile, leather, agricultural products' processing, etc. Among them, industrial products with national influence are iron and steel, military products, electromechanical products, and some chemical products.

\section{Sampling and analysis}

In January, 2015, the barks of Cinnamomum camphora in different functional areas, such as the Residential District (Shuxiangyulin, near the railway station), Commercial District (Bus Station), Industrial District (Xiangtan Iron \& Steel Co. Ltd of Hunan Valin, Longpai Food Limited by Share Co. Ltd) and Urban Green District (Baishi Park, Yuhu Park, Yuetang Park, Peace Park), were sampled (Fig. 1). The barks of 3-5 selected Cinnamomum camphora trees, which have similar age and a $25-45 \mathrm{~cm}$ diameter at breast height in one place, were taken from the same side of the trunk at 1.3$1.5 \mathrm{~m}$ above the ground surface. 
When sampling, the adhesives on the bark's surface were removed with a hard brush, then the barks of $5 \times 5 \mathrm{~cm}^{2}$ were scrape off with a stainless steel knife. To prevent contact pollution and increase the experiment error, polish the bark's surface with sandpaper. The samples were enclosed in a polyethylene self-sealing bag and numbered. Synchronously, the sampling point, sampling time, weather condition, geographical location, altitude and tree height, etc were recorded.

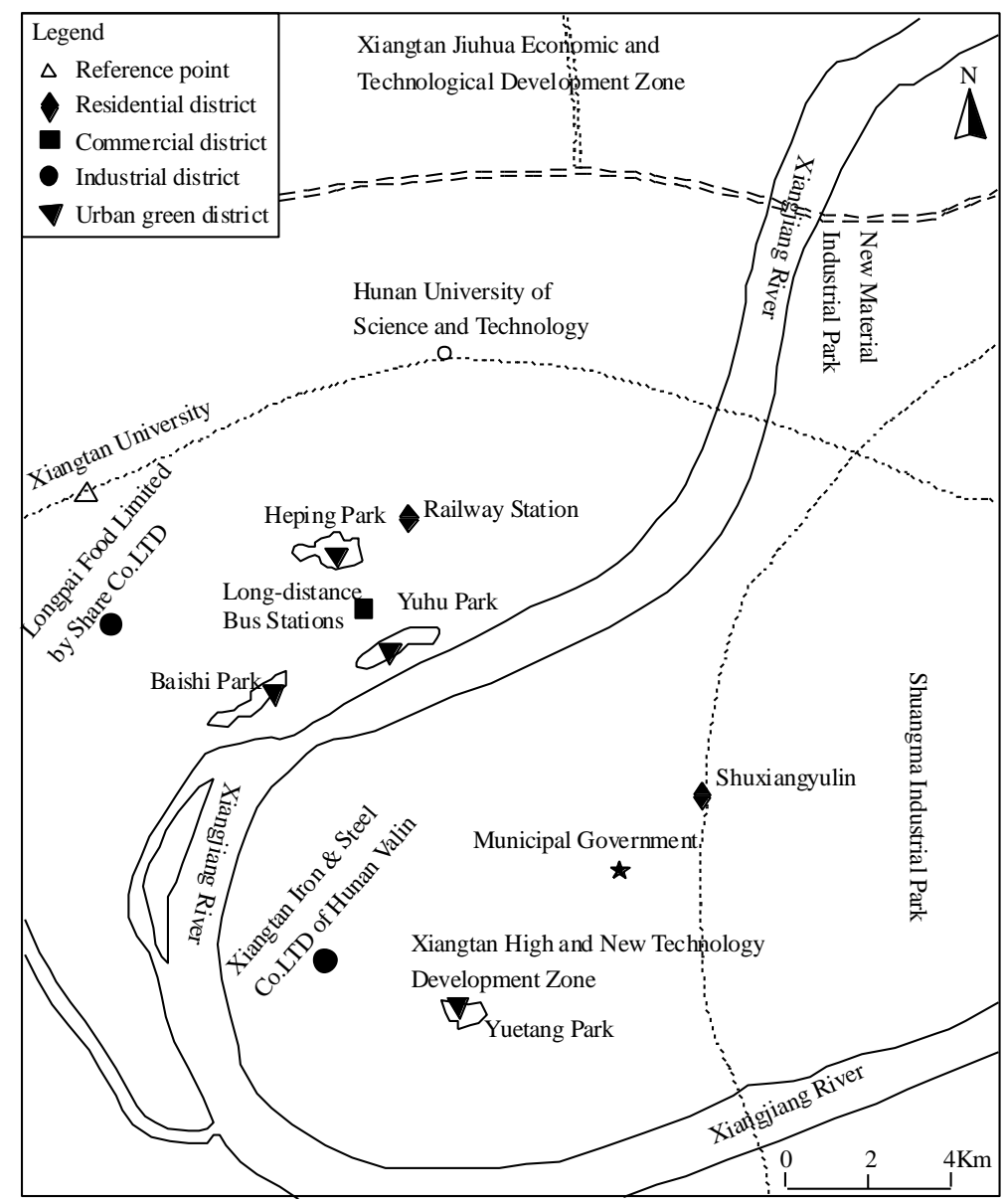

Figure 1. Schematic diagram of sampling sites

In the laboratory, the impurities were removed and the samples were baked to a constant weight at $105^{\circ} \mathrm{C}$ in a thermostat. Then, the dried sample was ground in an agate mortar through a 100 mesh nylon sieve. Next, $2 \mathrm{ml} \mathrm{HCL}, 5 \mathrm{ml} \mathrm{HNO}_{3}$ and $2 \mathrm{ml}$ $\mathrm{H}_{2} \mathrm{O}_{2}$ were added to $0.5 \mathrm{~g}$ ground samples that were digested by microwave digestion (Zhuang et al., 2000). Afterward, the digested samples were heated at $300{ }^{\circ} \mathrm{C}$ for $4 \mathrm{~h}$ by an electric heating plate to remove the acid. After sample treatment, a FAAS (flame atomic absorption spectrophotometer) was utilized to test the content of heavy metal (Cd, Pb, Cr, Cu, Mn) (Lü, 2008; Sharifi et al., 2017; Kord et al., 2010; Ahmad Afif, 2010; Xie et al., 2009). The correlation between the standard solution was at least 0.99, the error of the heavy metal content of the parallel sample was less than 5\%, and every five groups added a blank sample. All experimental data must be subtracted from the blank sample to ensure accuracy. 


\section{Results and analysis}

\section{Heavy metal contents in the bark of Cinnamomum camphora}

Because Xiangtan University is located in the suburb of Xiangtan City, we take the heavy metal contents in the barks of Cinnamomum camphora at Xiangtan University as preset reference values to reveal the regional differences due to its good environmental conditions (Fig. 2).

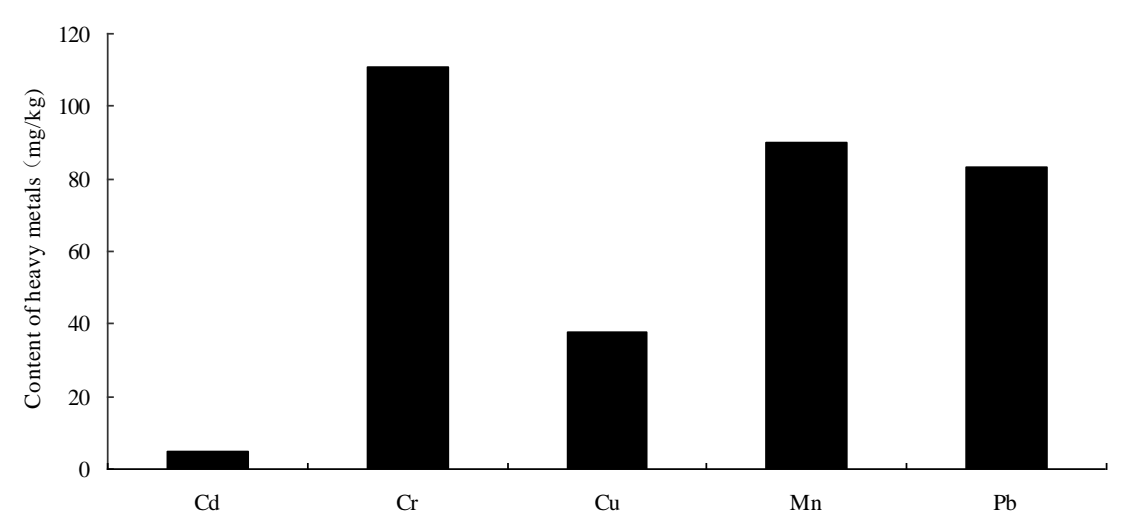

Figure 2. Contents of heavy metals in the bark of Cinnamomum camphora at Xiangtan University

The average content of Cd in Xiangtan is $5.35 \mathrm{mg} / \mathrm{kg}$, with a range of $2-10.0 \mathrm{mg} / \mathrm{kg}$; Average content of $\mathrm{Cr}$ is $117.35 \mathrm{mg} / \mathrm{kg}$, with a range of $42.0-266.0 \mathrm{mg} / \mathrm{kg}$; Average content of $\mathrm{Cu}$ is $44.376 \mathrm{mg} / \mathrm{kg}$, with a range of $23.74-126.42 \mathrm{mg} / \mathrm{kg}$; Average content of $\mathrm{Mn}$ is $304.529 \mathrm{mg} / \mathrm{kg}$, with a range of $19.5-1214.56 \mathrm{mg} / \mathrm{kg}$; Average content of $\mathrm{Cr}$ is $86.65 \mathrm{mg} / \mathrm{kg}$, with a range of 30.0-220.0 mg/kg (Tables 1 and 2). Average heavy metal content in the barks of Cinnamomum camphora was $\mathrm{Mn}>\mathrm{Cr}>\mathrm{Pb}>\mathrm{Cu}>\mathrm{Cd}$, and the content of $\mathrm{Mn}$ reached $304.529 \mathrm{mg} / \mathrm{kg}$. The content of $\mathrm{Mn}$ in Xiangtan has a high background value, which is a factor with local characteristics. The above situation may be related to the long-term mining of Mn in Xiangtan Manganese Mine. During over 100 years of mining, tailing, slag and sewage were not treated effectively and timely, resulting in the loss and diffusion of Mn. Manganese can diffuse into the atmosphere and soil through a variety of approaches (Xie et al., 2005; Xi et al., 2008). Plants can absorb manganese through their roots, accepting atmospheric deposition, and absorption function of plants themselves, so that the manganese content in plants reached a higher level.

\section{Heavy metal contents in the barks of Cinnamomum camphora in different functional districts and their sources}

Content and spatial distribution of heavy metals in the barks of Cinnamomum camphora were different in different functional regions in Xiangtan city (Table 2). The content of the heavy metals in each functional district is Industrial Area > residential area $>$ urban green area $>$ commercial area. Among them, the heavy metal content in the Industrial District was the highest, and the maximum value reached $1301.5 \mathrm{mg} / \mathrm{kg}$. The highest content of manganese also appeared in the Industrial District, reaching 
$736.68 \mathrm{mg} / \mathrm{kg}$. The maximum heavy metal contents in the Residential District reached $947.06 \mathrm{mg} / \mathrm{kg}$, and the contents of $\mathrm{Mn}, \mathrm{Cr}$, and $\mathrm{Pb}$ were relatively high. Urban Green Districts in this research were mainly urban parks, and their environments are relatively good. Overall, the heavy metal content of the barks of Cinnamomum camphora in Urban Green Districts is lower than that in industrial and Residential Districts. However, because Yuetang Park is located close to the old industrial zone of Xiangtan Iron \& Steel Co. Ltd of Hunan Valin, environmental pollution around Yuetang Park was severe, and the maximum heavy metal content reached $833.42 \mathrm{mg} / \mathrm{kg}$.

Table 1. Heavy metal contents in Cinnamomum camphora in Xiangtan $(\mathrm{mg} / \mathrm{kg})$

\begin{tabular}{c|c|c|c|c|c}
\hline Heavy metal & $\mathbf{C d}$ & $\mathbf{C r}$ & $\mathbf{C u}$ & $\mathbf{M n}$ & $\mathbf{P b}$ \\
\hline Average & 5.35 & 117.35 & 44.376 & 304.529 & 86.65 \\
Range & $2.0-10.0$ & $42.0-266.0$ & $23.74-126.42$ & $19.5-1214.56$ & $30.0-220.0$ \\
Standard deviation & 1.994 & 51.089 & 19.242 & 261.859 & 42.944 \\
\hline
\end{tabular}

Table 2. Fundamental characteristics of heavy metal in the barks of Cinnamomum camphora in different functional districts $(\mathrm{mg} / \mathrm{kg}$ )

\begin{tabular}{c|c|c|c|c|c|c|c}
\hline Functional district & & $\mathbf{C d}$ & $\mathbf{C r}$ & $\mathbf{C u}$ & $\mathbf{M n}$ & $\mathbf{P b}$ & Total \\
\hline \multirow{3}{*}{ Residential district } & Maximum & 8 & 124 & 43.82 & 653.24 & 118 & 947.06 \\
& Minimum & 4 & 46 & 29.16 & 77.08 & 60 & 216.24 \\
& Average & 5.3 & 104 & 33.66 & 318.78 & 79.67 & 541.41 \\
\hline \multirow{3}{*}{ Commercial district } & Maximum & 6 & 162 & 126.42 & 222.94 & 104 & 621.36 \\
& Minimum & 4 & 78 & 39.18 & 84.36 & 30 & 235.54 \\
& Average & 4.33 & 113.67 & 65.81 & 161.82 & 59.67 & 405.3 \\
\hline \multirow{3}{*}{ Industrial district } & Maximum & 10 & 266 & 68.52 & 736.68 & 220 & 1301.2 \\
& Minimum & 4 & 78 & 39.96 & 169.14 & 92 & 383.1 \\
& Average & 6.5 & 164.25 & 53.37 & 405.33 & 133.75 & 763.2 \\
\hline \multirow{3}{*}{ Urban green district } & Maximum & 10 & 150 & 65.44 & 330.86 & 144 & 700.3 \\
& Minimum & 2 & 42 & 23.74 & 115.36 & 32 & 215.1 \\
& Average & 5.29 & 94.57 & 37.92 & 221.73 & 67.57 & 427.08 \\
\hline \multirow{3}{*}{ Reference point } & Maximum & 6 & 150 & 37.64 & 149.5 & 182 & 525.14 \\
& Minimum & 4 & 106 & 35.32 & 69.16 & 52 & 266.48 \\
& Average & 5 & 125 & 36.74 & 126.68 & 102.33 & 395.75 \\
\hline
\end{tabular}

The sources of heavy metal pollution in cities are exceptionally incredible, and the primary pollution sources in diverse functional areas are different. The highest heavy metal content in the barks of Cinnamomum camphora in Xiangtan is Mn due to the exploitation of Xiangtan Manganese Mine. However, the content of manganese is different in various functional areas (Table 3; Fig. 3). The manganese content in Shuxianglin was $333.96 \mathrm{mg} / \mathrm{kg}$, ranking third in all sampling sites. Besides $\mathrm{Mn}$, the content of $\mathrm{Cr}$ and $\mathrm{Pb}$ was relatively high, reaching $160 \mathrm{mg} / \mathrm{kg}$ and $78 \mathrm{mg} / \mathrm{kg}$ respectively. The dense buildings, less greening area, a large population density, large living garbage, living sewage and a large amount of exhaust gas from the combustion of domestic fuel near this district led to the high content of $\mathrm{Mn}, \mathrm{Cr}$, and $\mathrm{Pb}$. Besides, 
Shuxiangyulin Community is next to Ji'an Road and not far away from the Xiangtan East Automobile Station. Barks of Cinnamomum camphora might accumulate a large amount of automobile exhaust and road dust due to the huge traffic flow, which may also be the reason for the high content of $\mathrm{Cr}$ and $\mathrm{Pb}$. The minimum values of $\mathrm{Cr}$ and $\mathrm{Mn}$ appeared near the Railway Station, reaching $68 \mathrm{mg} / \mathrm{kg}$ and $78.12 \mathrm{mg} / \mathrm{kg}$. The principal reasons are its location close to the suburbs, the low buildings and the small traffic flow of the adjacent roads.

Table 3. Heavy metal content in different sampling areas of different functional districts $(\mathrm{mg} / \mathrm{kg})$

\begin{tabular}{|c|c|c|c|c|c|c|c|}
\hline Functional district & Site & Cd & $\mathrm{Cr}$ & $\mathrm{Cu}$ & Mn & $\mathbf{P b}$ & Total \\
\hline \multirow{2}{*}{ Residential district } & Shuxiangyulin & 5 & 160 & 31.08 & 333.96 & 78 & 608.04 \\
\hline & Near the railway station & 4 & 68 & 30.7 & 78.12 & 67 & 247.82 \\
\hline Commercial district & Bus station & 5 & 137 & 48.83 & 214.83 & 92 & 497.66 \\
\hline \multirow{2}{*}{ Industrial district } & $\begin{array}{c}\text { Longpai Food Limited by } \\
\text { Share Co. Ltd }\end{array}$ & 6 & 210 & 39.96 & 233.28 & 114 & 603.24 \\
\hline & $\begin{array}{l}\text { Xiangtan Iron \& Steel Co. } \\
\text { Ltd of Hunan Valin }\end{array}$ & 8 & 79 & 62.34 & 712.89 & 202 & 1064.23 \\
\hline \multirow{4}{*}{ Urban green district } & Baishi Park & 3 & 101 & 32.62 & 127.08 & 71 & 334.7 \\
\hline & Yuhu Park & 8 & 54 & 29.15 & 119.67 & 59 & 269.82 \\
\hline & Yuetang Park & 6 & 82 & 34.94 & 304.48 & 77 & 504.42 \\
\hline & Peace Park & 4 & 68 & 33.79 & 168.82 & 43 & 317.61 \\
\hline Reference site & Xiangtan University & 5 & 111 & 37.64 & 89.85 & 83 & 326.49 \\
\hline
\end{tabular}

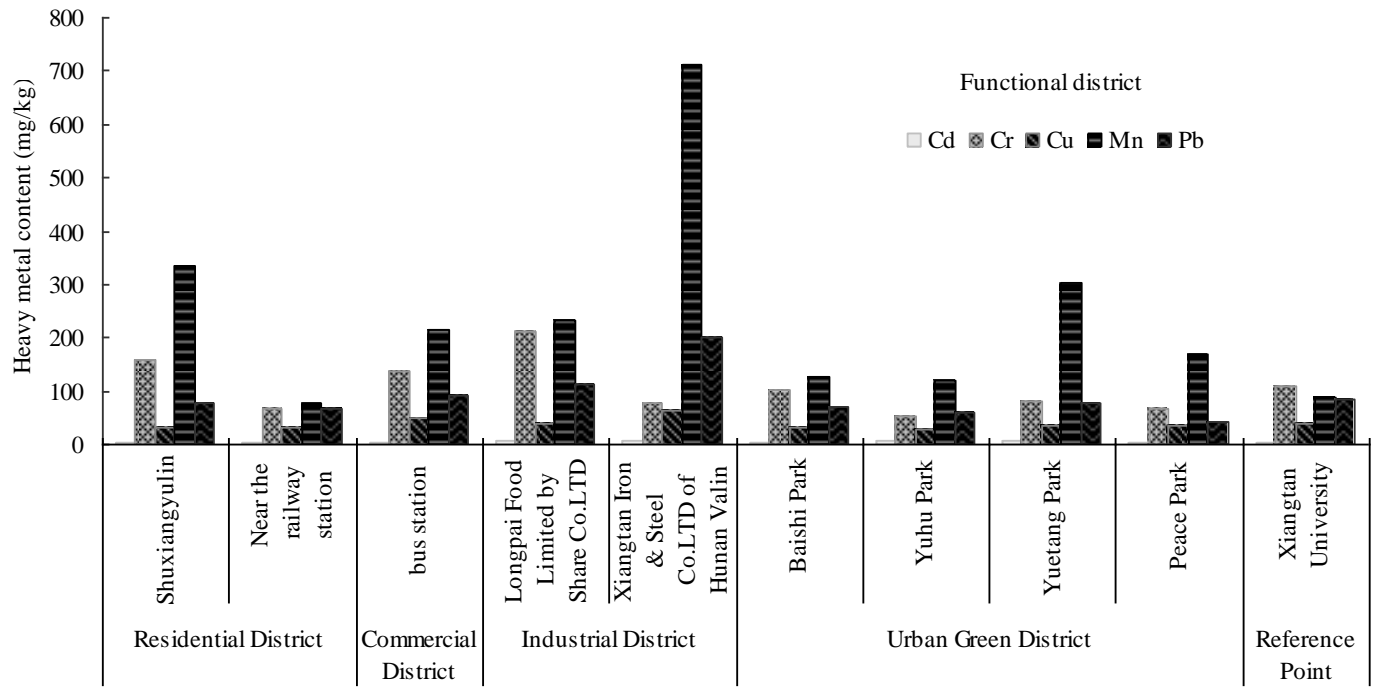

Figure 3. Contents of heavy metals in the barks of Cinnamomum camphora in different functional areas

The contents of $\mathrm{Cd}, \mathrm{Cr}, \mathrm{Cu}, \mathrm{Mn}$ and $\mathrm{Pb}$ in the barks of Cinnamomum camphora were high in the Commercial District. The Long-distance Bus Station, as an essential part of the Commercial District, is located in the centre of Xiangtan City and has various food, 
accommodation and entertainment industries, resulting in more garbage compared to other areas. Moreover, a large number of heavy metals can be produced by exhaust emissions from vehicle fuel combustion and dust in this district because of the massive traffic volume. These heavy metals will enter the atmosphere, and then accumulate on the surface of the barks of Cinnamomum camphora through atmospheric sedimentation and plant adsorption.

In the Industrial District, the heavy metal contents in the barks of Cinnamomum camphora are very high (Tables 2 and 3; Fig. 3). The maximum value of $\mathrm{Mn}$ and $\mathrm{Pb}$ both found in Xiangtan Iron \& Steel Co. Ltd of Hunan Valin (Fig. 3) and reached $712.89 \mathrm{mg} / \mathrm{kg}, 7.9$ times that of the reference point. The content of $\mathrm{Pb}$ reached $202 \mathrm{mg} / \mathrm{kg}, 2.4$ times that of the reference point. The main reason why the heavy metal content of Xiangtan Iron \& Steel Co. Ltd is so high is that it is a long-standing iron and steel enterprise with a complete set of technological processes, such as coking, sintering, ironmaking, steelmaking, rolled materials and so on. A large number of waste gas, wastewater, and residues containing $\mathrm{Mn}, \mathrm{Pb}, \mathrm{Cd}$, and other heavy metals can discharge during the production process, and then enter the atmosphere and soil. After atmospheric deposition and rain wash, the heavy metal would accumulate in plants by absorption and adsorption through roots and barks. Therefore, the heavy metal contents in the barks of Cinnamomum camphora were high. At Longpai Food Limited by Share Co. Ltd, due to small greening, dense buildings and large traffic volume, the contents of $\mathrm{Cr}, \mathrm{Mn}, \mathrm{Pb}$, and other heavy metals in the barks of Cinnamomum camphora are also relatively high, reaching $210 \mathrm{mg} / \mathrm{kg}, 233.28 \mathrm{mg} / \mathrm{kg}$ and $114 \mathrm{mg} / \mathrm{kg}$, respectively.

Although Yuetang Park is an urban green space, it is located in the old industrial area and has a long history. Besides, it is close to Xiangtan Iron \& Steel Co. Ltd, a critical pollutant enterprise. Therefore, the content of $\mathrm{Mn}$ in the barks of Cinnamomum camphora in this area even reaches a high level of $304.48 \mathrm{mg} / \mathrm{kg}$, which is the place where the maximum content of $\mathrm{Mn}$ and $\mathrm{Pb}$ appears in urban green space. From Table 3, the highest content of $\mathrm{Cr}$ appears in Baishi Park, and the content is $101 \mathrm{mg} / \mathrm{kg}$. Baishi Park lies in the old city centre of Xiangtan. There are more residents around it, and the traffic flow near the sampling point is also significant. Similar to other places with the high contents of heavy metal, road dust and living sewage are the main reasons for the high content of $\mathrm{Cr}$ in this area.

\section{Conclusion}

Heavy metal contents in the barks of Cinnamomum camphora had a specific accumulation and could indicate the air pollution condition in Xiangtan. The results showed that:

- The contents of $\mathrm{Cr}, \mathrm{Mn}$, and $\mathrm{Pb}$ in the barks of Cinnamomum camphora were the highest. Among them, the content of Mn exceeded seriously, and the average content was Industrial District > Residential District > Urban Green District >Commercial District. The maximum value of $\mathrm{Mn}$ appeared at Xiangtan Iron and Steel Co., with a high value of $712.89 \mathrm{mg} / \mathrm{kg}$, which was 7.9 times the reference point.

- Heavy metals in the barks of Cinnamomum camphora mainly were produced by traffic discharge, living waste, manganese mining, and industrial enterprise discharge. The heavy metal contents in the barks of Cinnamomum camphora in the industrial area and its adjacent urban green space was high, which was 
mainly due to the production and emission of industrial enterprises. For Commercial Districts, the high contents of heavy metal were affected primarily by the traffic flow, automobile exhaust, and domestic waste. Population density and domestic waste were the significant factors affecting the heavy metal in the barks of Cinnamomum camphora in Residential Districts. Although some urban green space has a good environment and a vast green area, the heavy metal content in the barks of Cinnamomum camphora was high because of the influence of living waste and the surrounding environment.

- Bark has broad application prospects in monitoring environmental heavy metal pollution, but the current research is far from enough. Combining various biological monitoring methods (e.g., moss, leaves, barks, and roots), improving testing techniques and seeking more geochemical means will be the direction of future efforts.

\section{REFERENCES}

[1] Ahmad Afif, H. (2010): Biomarker as Indicator of Aerial Dispersal of Heavy Metal within Remediated and Abandoned Tin Mine Site. - Universiti Teknologi Petronas, Perak, Malaysia.

[2] Chen, B., Lu, S., Li, S., Lu, S., Shi, Y., Li, L. (2016): Analysis of heavy metal and sulfur absorption ability of trees under different pollution gradients in Tianjin City. - Research of Soil and Water Conservation 23(1): 175-182.

[3] El-Hasan, T., Al-Omari, H., Jiries, A., Al-Nasir, F. (2002): Cypress tree (Cupressus semervirens L.) bark as an indicator for heavy metal pollution in the atmosphere of Amman City, Jordan. - Environment International 28(6): 513-519.

[4] Fang, Y., Wei, Y., Zhang, X., Yang, K. (2000): Advances in bry-monitoring of atmospheric heavy metal pollution. - Journal of Nanjing Forestry University 24(5): 6468 .

[5] Huang, H., Zhang, C., Zhang, Y., Jiang, D., Wang, Y. (1983): Study on absorption and accumulation of heavy metal pollutants in the woody plants. - Acta Ecologica Sinica 3(4): 11-19.

[6] Huang, H., Zhang, C., Zhang, Y., Jiang, D., Wang, Y. (1984): Study on tolerance of woody-plants to heavy metal pollutants in air. - Acta Phytoecologica et Geobotantica Sinica 8(2): 41-50.

[7] Kord, B., Mataji, A., Babaie, S. (2010): Pine (Pinus Eldarica, Medw.) needles as indicator for heavy metals pollution. - International Journal of Environmental Science \& Technology 7(1): 79-84.

[8] Lü, C. (2008): Review on the detection methods of heavy metals. - Resource Development \& Market 24(10): 887-890.

[9] Sharifi, R., Baboli, M. J., Roomiani, L. (2017): Essential heavy metal concentrations (Zn, $\mathrm{Fe}, \mathrm{Cu}, \mathrm{Mg}$ and $\mathrm{Mn}$ ) in muscle tissue of green tiger shrimp, Penaeus semisulcatus, with different size classes. - Journal of Animal \& Plant Sciences 27(4): 1402-1407.

[10] Sun, X., Tang, W. (2011): Research on plant monitoring and analysis of Fushun heavy metal pollution in atmosphere. - Environmental Science and Management 36(9): 122124.

[11] Xi, C., Dai, T., Zhang, H., Liu, W. (2008): Investigation and assessment on pollution of soil heavy metals in Xiangtan City. - Bulletin of Soil and Water Conservation 28(3): 133137.

[12] Xiao, Z. (1996): Eco-environmental disasters and their developmental tendency in Hunan Province. - Chinese Journal of Ecology 1: 51-56. 
[13] Xie, R., Tian, D., Fang, X. (2005): Assessment of pollution of heavy metals on the slag wasteland of Xiangtan manganese mine. - Journal of Central South University of Forestry \& Technology 25(2): 38-41.

[14] Xie, Y., Cao, Y. (2009): Determination of heavy metals in corn leaves by atomic absorption spectrophotometry. - Journal of Jilin Institute of Chemical Technology 26(2): 35-39.

[15] Yao, L., Liao, X., Zhang, H., Ling, C., Yu, Z. (1998): Progress and trend of atmospheric heavy metal pollution in China. - Environmental Science and Management 37(9): 41-44.

[16] Yu, G., Yuan, K., Wang, X., Mo, H. (2012): Classification of environmental disaster in Hunan Province. - Disaster Advances 5(4): 195-200.

[17] Zhang, N. (1998): The present situation and prospect of research on heavy metal pollution in soil-plant system. - Chinese Journal of Environmental Engineering 7(4): 3033.

[18] Zhang, Y., Su, J., Jiang, W., Huang, Z., Xiang, Y., Zeng, F. (2012): Study on the heavy metal pollution evaluation and countermeasures of middle size and small cities in typical drainage area - taking Xiangtan reach of Xiangjiang River as an example. - Research Journal of Chemistry and Environment 16: 172-179.

[19] Zhou, L., Zhang, X., Yang, W., Li, L., Shi, S., Zhang, L., Dong, L., Huang, Y. (2014): Levels and Possible Sources of Organochlorine Pesticides (OCPs) in Camphor (Cinnamomum camphora) Tree Bark from Southern Jiangsu, China. - Environmental Science 35(3): 1159-1163.

[20] Zhu, W., Bian, B., Ruan, A. (2007): Analysis of sources of heavy metal contamination in road-deposited sediment from Zhenjiang. - Environmental Science 28(7): 1584-1589.

[21] Zhuang, S., Wang, K. (2000): Study on the relationship between atmospheric heavy metal pollution $(\mathrm{Pb}, \mathrm{Cd}, \mathrm{Cu}, \mathrm{Zn})$ and its accumulations in leaves of urban trees. - Journal of Yantai University (Natural Science and Engineering Edition) 13(1): 33-39. 